\title{
Alteration in Serum Concentration of Canine C-Reactive Protein (CRP) Associated with Canine Monocytic Ehrlichiosis (CME) and its Amelioration by Conventional Treatment
}

\author{
Jaideep Singh ${ }^{1}$, Mukesh Kumar Srivastava ${ }^{1}$, Kapil Kumar Gupta ${ }^{2 *}$, Vikrant Sudan ${ }^{3}$, \\ Ashish Srivastava ${ }^{1}$ and Barkha Sharma ${ }^{4}$ \\ ${ }^{1}$ Department of Veterinary Medicine, DUVASU, Mathura, U.P., INDIA \\ ${ }^{2}$ Division of Medicine, IVRI, Izatnagar, Bareilly, U.P., INDIA \\ ${ }^{3}$ Department of Veterinary Parasitology, DUVASU, Mathura, U.P., INDIA \\ ${ }^{4}$ Department of Veterinary Public Health and Epidemiology, DUVASU, Mathura, U.P., INDIA \\ "Corresponding author: KK Gupta: E-mail: dr.kapil09@gmail.com
}

Received: 05 June, 2021

Revised: 18 Sept., 2021

Accepted: 22 Sept., 2021

\begin{abstract}
Present investigation has recorded ehrlichiosis associated C-reactive protein status in dogs. Total 79 dogs were screened for ehrlichiosis based on the clinical diagnosis criteria. All the screened dogs underwent for blood smear examination followed by primary and nested PCR analysis which confirm total $64 \mathrm{dog}$ positive for ehrlichiosis. These confirmed cases were taken for further analysis to assess the extent of inflammation caused by acute phase protein such as C-reactive protein. Results of present investigation revealed significant increase in serum concentration of canine C-reactive protein in ehrlichiosis affected dogs as compared to healthy ones. Conventional treatment of diseased animals reduces these values towards the reference values as assessed in healthy animals. It can be concluded thatserum level of C-reactive protein is significantly increases in case of canine monocytic ehrlichiosis and can be used as potent clinical biomarker for assessment of extra cytokines induced inflammatory reaction.
\end{abstract}

\section{HIGHLIGHTS}

(0 Canine Monocytic Ehrlichiosis causes severe inflammation as evident by increased serum level of cytokine.

( $\mathrm{CRP}$ is an extra-cytokinin biomarkers for inflammation associated with canine ehrlichiosis.

0 In ehrlichiosis affected dog significant increase in canine $\mathrm{C}$ reactive protein has been observed.

Keywords: C-Reactive Protein, Ehrlichiosis, PCR, Cytokines

Canine monocytic ehrlichiosis (CME) is defined as an inflammatory, tick transmitted, multisystemic disease caused by intracellular parasite known as Ehrlichia canis (Barman et al., 2014). Clinically the disease can be identified by pyrexia, depression, lethargy, subcutaneous haemorrhage, epistaxis, lymphadenopathy (Harrus and Waner, 2011), spleenomegaly and thrombocytopenia (Sainz et al., 2015). Disease may occur in acute, subacute or chronic form. Infection is common in both the sexes of all age but some serological studies suggested higher occurrence of disease in male animals. Ehrlichia canis has reported to cause a significant inflammatory response in dogs as evident by increased acute phase proteins (APPs) such as C-reactive protein or haptoglobin (Karnezi et al., 2016). This appears to occur via a variety of mechanisms particularly via infiltration of the sub endothelial layer and perivascular region of multiple organs with lymphocytes,

How to cite this article: Sharma, M., Thakur, M.S., Joshi, S., Tantia, M.S., Sharma, R., Singh, A.P., Pandey, A., Khare, V., Vandre, R.K. and Khan, A. (2021). Phenotypic Characterization of Non-descript Cattle of Mahakaushal Region of Madhya Pradesh. J. Anim. Res., 11(05): 795-800. Source of Support: None; Conflict of Interest: None 
monocytes/macrophages, and plasma cells (Abiramalatha et al., 2016). Previous studies reported the increase in Canine C-reactive protein in dogs affected with immune mediated polyarthritis (Kjelgaard-Hansen et al., 2006) and canine tick-borne diseases (Asawakarnand Taweethavonsawat, 2021). The kinetic properties of canine CRP during an acute phase response are characterized by a low concentration at normal homeostasis, a short lagphase after the inflammatory stimulus of around 4 hours (Higgins et al., 2003), reaching a peak in concentration after approximately 24 hours, and a quick normalization after ended inflammatory stimulus (Hayashi et al., 2001). Keeping in view the above discussion present study has been designed to evaluate the alternation in serum concentration of canine C-reactive protein in dog affected with ehrlichiosis.

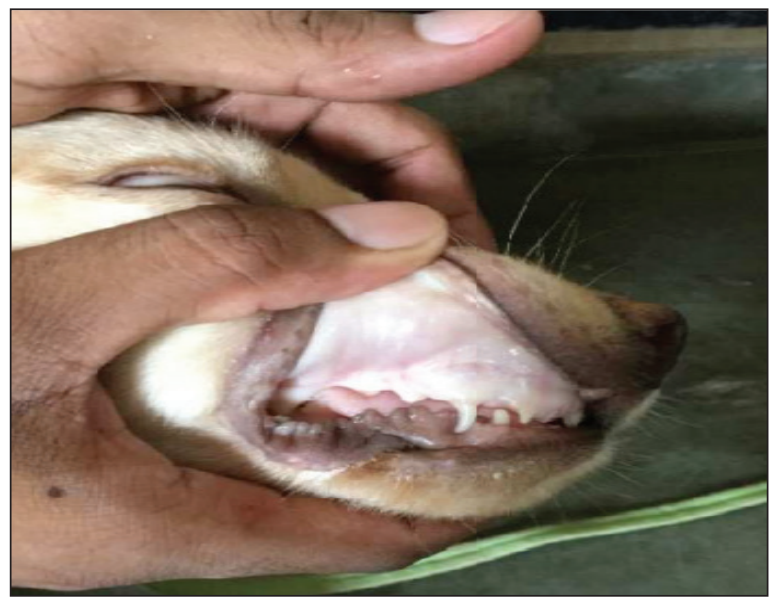

Fig. 1: Pale mucus membrane

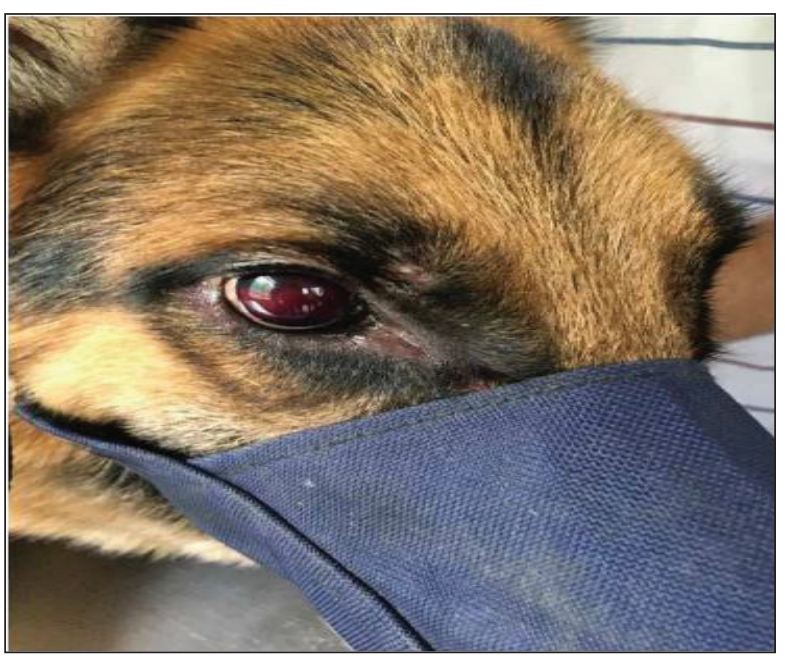

Fig. 3: Hyphema in GSD

\section{MATERIALS AND METHODS}

\section{Screening of dogs for study}

Screening of dogs, suspected for Ehrlichiosis was done on the basis of observation of classical signs of Ehrlichia in dogs. Based on results of previous studies, clinical signs considered for screening are mucosal pallor, high fever, lymphadenomegaly, epistaxis, splenomegaly, hyphema, depression, ocular abnormalities, vomiting, haematuria, melena, haematemesis, hind limb /or scrotal edema, bleeding diathesis, icterus, central nervous system signs, ascites and weight loss (Fig. 1-4). Dogs with above mentioned 2-3 classical signs of ehrlichiosis listed above will be included in screening procedure. Dogs' positive

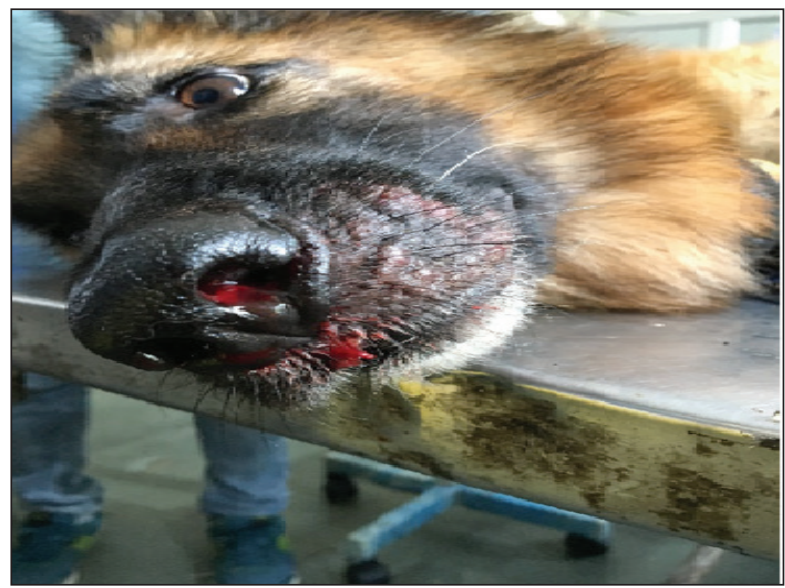

Fig. 2: Epistaxis in GSD

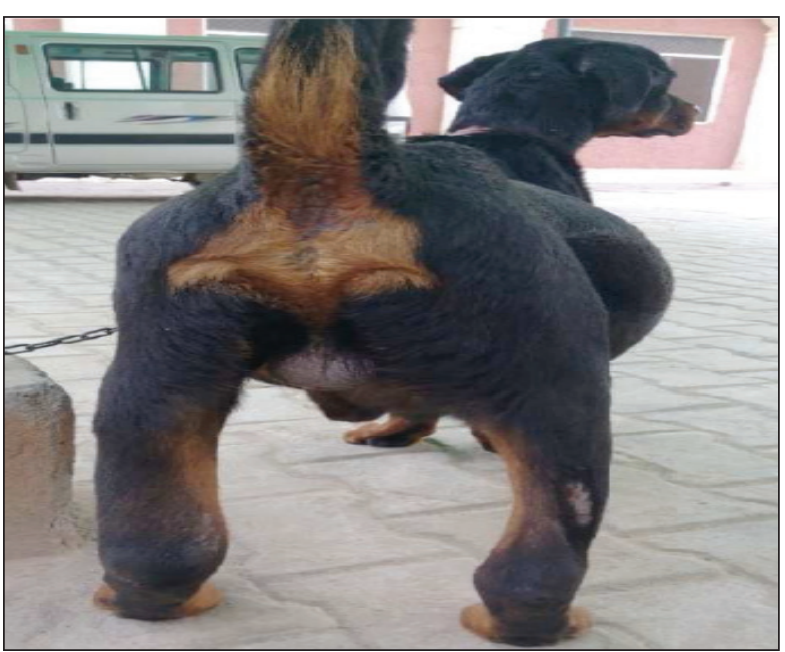

Fig. 4: Limb edema in Rottweiler 
for ehrlichiosis with a concurrent disease and dog without proper history of vaccination and deworming were excluded from screening procedure. A total of seventynine (79) dogs were screened in the present investigation, which were presented to Veterinary Clinical Complex, DUVASU, Mathura between August 2018 to April 2019.

\section{Confirmation of screened dogs for ehrlichiosis}

Screened dogs further underwent a series of diagnostic procedure to confirm the disease. The primary confirmation of canine monocytic ehrlichiosis was done by detection of morulae in monocytes in the blood smear (Fig. 5) which was taken from ear tip and stained by Leishman stain.

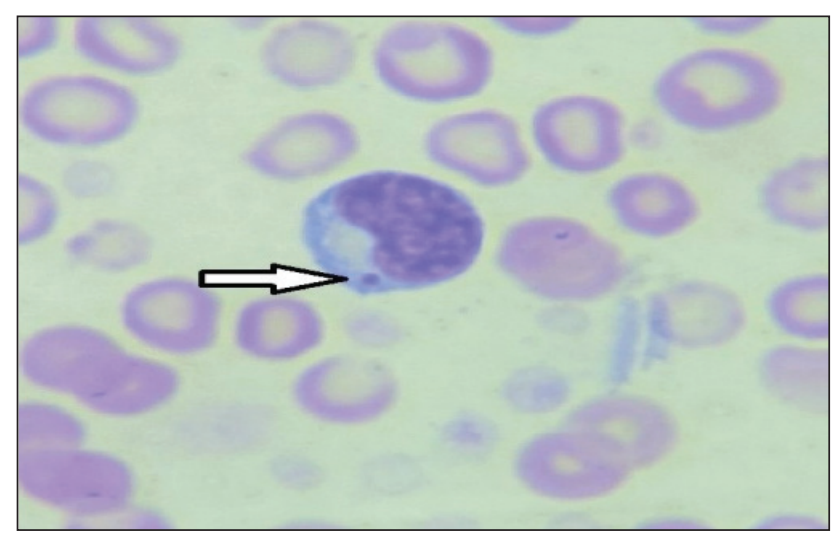

Fig. 5: Morula in Monocytes

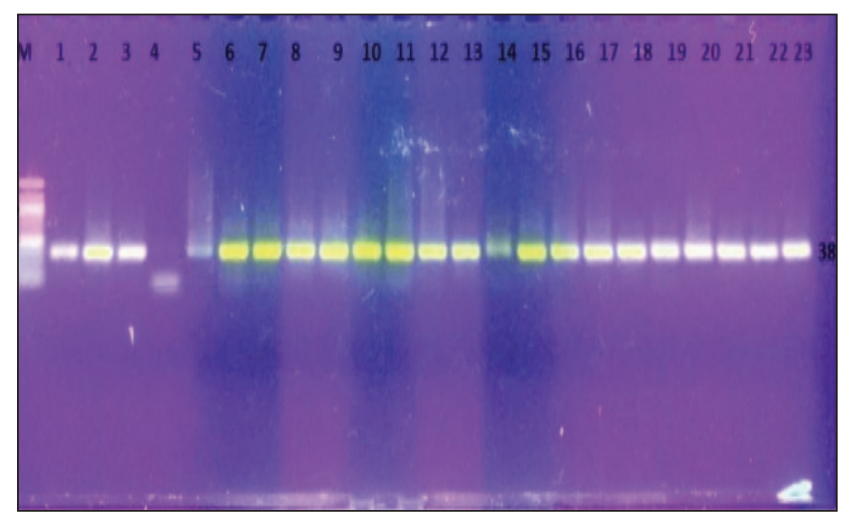

Fig. 6: Result of nested PCR ( $M=$ Marker of $100 \mathrm{bp}$, Lane 1-23 $=$ Sample, primer: $460-540 \mathrm{bp}$ )

Dogs having symptoms of CME but negative for blood smear examination were further confirmed by polymerase chain reaction (PCR) test. Out of 79 screened samples, Sixty-four (64) samples were found positive for ehrlichiosis on the basis of Nested PCR which were used for further clinical studies. Out of these $64 \mathrm{dogs}, 42$ dogs were taken for therapeutic study. Specific primer pairs were used for $E$. canis gene (16 S rRNA). Details of primers and thermal cycling profile used for nested PCR analysis are given in table 1 . Amplification reactions were carried out in Thermocycler (BioRad, USA). PCR results were analysed using agarose gel electrophoresis under UV light (Fig. 6).

Table 1: Details of primer and thermal cycling profile for nested PCR analysis of Ehrlichia canis

\begin{tabular}{|c|c|c|}
\hline Species & \multicolumn{2}{|l|}{ Ehrlichia canis } \\
\hline \multirow[t]{2}{*}{$\begin{array}{l}\text { Primer } \\
\text { sequence }\end{array}$} & \multicolumn{2}{|c|}{$\begin{array}{l}\text { ECAN5: 5'- CAATTATTTATAGCCTCTGGCTC } \\
\text { TGGCTATAGGA-3' }\end{array}$} \\
\hline & \multicolumn{2}{|c|}{$\begin{array}{l}\text { HE3: 5'- TATAGGTACCGTCATTATCTTCCCTAT- } \\
\text { 3' }\end{array}$} \\
\hline \multirow{7}{*}{$\begin{array}{l}\text { Thermal } \\
\text { cycling } \\
\text { profile }\end{array}$} & \multicolumn{2}{|c|}{ Initial denaturation- $94{ }^{\circ} \mathrm{C}$ for $3 \mathrm{~min}$} \\
\hline & First step & Second step \\
\hline & $\begin{array}{l}\text { Denaturation ( } 3 \text { cycles)- } 94 \\
{ }^{\circ} \mathrm{C} \text { for } 1 \mathrm{~min}\end{array}$ & $\begin{array}{l}\text { Denaturation }(37 \\
\text { cycles)- } 94{ }^{\circ} \mathrm{C} \text { for } 1\end{array}$ \\
\hline & Annealing- $55^{\circ} \mathrm{C}$ for $2 \mathrm{~min}$ & \\
\hline & \multirow[t]{3}{*}{ Extension- $72{ }^{\circ} \mathrm{C}$ for $1.5 \mathrm{~min}$} & $\begin{array}{l}\text { Annealing- } 55^{\circ} \mathrm{C} \text { for } \\
2 \mathrm{~min}\end{array}$ \\
\hline & & $\begin{array}{l}\text { Extension- } 72^{\circ} \mathrm{C} \text { for } \\
1.5 \text { min }\end{array}$ \\
\hline & & $\begin{array}{l}\text { Final extension- } 72{ }^{\circ} \mathrm{C} \\
\text { for } 8 \text { min }\end{array}$ \\
\hline
\end{tabular}

\section{Determination of Canine C-Reactive Protein}

These parameters were analyzed by using commercial ELISA kit (Canine C-Reactive protein, CRP ELISA kit, catalog no.-YHB0022Ca-48T, Gentaur) as per the manufacturer's protocol and results were summarized in tabular form for easy understanding.

\section{Therapeutic study}

The dogs were grouped in two groups having six dogs in group 1 (control) and 42 dogs in group 2 (Treatment). Treatment group has been treated with conventional treatment for canine ehrlichiosis. 
Singh et al.

\begin{tabular}{|l|l|}
\hline $\begin{array}{l}\text { Group-I (Controlor } \\
\text { healthy) }(\mathrm{N}=06)\end{array}$ & $\begin{array}{l}\text { At six healthy dogs, irrespective of breed, } \\
\text { age and sex. Apparently healthy animals } \\
\text { on the basis of clinicalexamination and } \\
\text { confirmed by same panel of test used for } \\
\text { Group II }\end{array}$ \\
\hline $\begin{array}{l}\text { Group-II } \\
\text { (Treatment) (N=42) }\end{array}$ & $\begin{array}{l}42 \text { clinical cases of dogs suffering from } \\
\text { ehrlichiosis } \\
\text { (Irrespective of breed, age and sex). }\end{array}$ \\
\hline
\end{tabular}

Conventional treatment used in this study is as follows:

$\square \quad$ Tab. Doxycycline @ 5 mg/kg.bwt twice a day for 21 days.

$\square \quad$ Tab. Carprofen@2.2 mg/kg.bwt twice a day in case of fever, (if required).

$\square \quad$ Tab. Pantoprazole @ 1 mg/kg.bwt once a day (if required).

$\square \quad$ Syp. Sucralfate @ 1 gm, thrice a day, (if required).

$\square \quad$ Other need based supportive and fluid therapy (if required).

\section{STATISTICAL ANALYSIS}

Web based Agricultural Statistics Software Package (WASP2) icargoa.res.in /wasp2.0/index.php was used for analysis of data.

\section{RESULTS AND DISCISSION}

$\mathrm{C}$-Reactive protein (CRP) values of control and diseased (Pre-treatment and post treatment) group have been summarized in the table 2 . The Mean $\pm \mathrm{SE}$ values of CRP concentration on day zero and day 14 of healthy dogs (group 1) were $1.75 \pm 0.07,1.78 \pm .04$ respectively while these value in diseased dogs at day zero and day 14 post treatment were $6.28 \pm .81$ and $2.54 \pm .18$ respectively. Test of significance showed that CRP concentration value of treatment groups were significantly higher than that of control group on the day of presentation. There was significant decrease in the mean CRP concentration value on day 14 post-treatment in the treatment groups. The present findings of increase in CRP concentration in cases of ehrlichiosis are in agreement with the findings of many previous studies (Shimada et al., 2002). Evaluation of certain inflammatory mediators like acute phase protein (for example C-reactive protein) or haptoglobinhas proved that significant inflammatory response is associated with Ehrlichia canis has infection (Karnezi et al., 2016).

This appears to occur via a variety of mechanisms particularly via infiltration of the sub endothelial layer and perivascular region of multiple organs with lymphocytes, monocytes/macrophages, and plasma cells (Abiramalatha et al., 2016). The kinetic properties of canine CRP during an acute phase response are characterized by a low concentration at normal homeostasis (Otabe et al., 2000), a short lag-phase after the inflammatory stimulus of around 4 hours (Higgins et al., 2003), reaching a peak in concentration after approximately 24 hours, and a quick normalization after ended inflammatory stimulus (Hayashi et al., 2001). Thus, canine CRP has the properties of an almost real time marker of the inflammatory activity during an acute phase response. A positive relationship has been established between increase in CRP values and magnitude of secondary bacterial infection (Cirvoni et al., 2012). A reduction in level of CRP was recorded after treatment of ehrlichiosis affected dogs in present investigation, which is in accordance with Capsi et al. (1987), which might be due to the general down regulation of inflammatory activity after treatment. APPs are part of the nonspecific reaction of the innate immune system, which is the organism's first line of defense at the early stages of the disease. This physiological mechanism allows time for the organism to activate other more specific lines of defense, such as cellular and humoral immune responses (Ceron et al., 2005). Thus, increased plasma CRP concentrations in the acute stages of $E$. canis infection may help to kill $E$. canis in the macrophages of infected dogs, controlling the infection at a subclinical level. (Rikihisa et al., 1994). The liver has been identified as the major site for production and release of acute phase proteins and interleukin- 6 is considered the major inducing cytokine of the hepatic production of CRP. Interleukin-1 and TNF-alpha that is traditionally also considered as major pro-inflammatory cytokines seem not able to induce the hepatic synthesis of CRP alone or in combination, but should still be considered as major co-working modulators. In addition to ehrlichiosis, plasma concentrations of CRP are reported to be increased in many infectious and inflammatory conditions, such as surgical trauma (Eckersall et al., 2007; Petersen et al., 2004), polyarthritis, leptospirosis, bacterial and haemorrhagic enteritis, parvoviral infection and leishmaniasis (Ceron et al., 2005). CRP inhibits 
chemotaxis and modulates neutrophil function, binds to bacteria activating the complement pathway and induces anti-inflammatory cytokine production (Ceron et al., 2005). Therefore, the changes in CRP concentrations in blood observed in various stages of disease activity are indirect indications of the participation of these cytokines in the pathogenic process (Eckersall, 2000).

Table 2: C-reactive protein alterations in various groups of dogs suffering from Canine Ehrlichiosis

\begin{tabular}{llc}
\hline \multirow{2}{*}{ Groups } & \multicolumn{2}{c}{$\begin{array}{r}\text { C-Reactive protein conc. } \\
\text { (mg/L) }\end{array}$} \\
\cline { 2 - 3 } & Day 0 & Day 14 \\
\hline G1 (Control, N=06) & $1.75 \pm .07^{\mathrm{a}}$ & $1.78 \pm .04^{\mathrm{a}}$ \\
G2 (Diseased, N=42) & $6.28 \pm .81^{\mathrm{Bb}}$ & $2.54 \pm .18^{\mathrm{Ab}}$ \\
\hline
\end{tabular}

Mean with different superscript $(a, b$,$) in columns are differing$ significantly in between the groups, otherwise non-significant. Mean with different superscript (A, B) in rows are differing significantly in between the intervals, otherwise non-significant.

\section{CONCLUSION}

Present findings clearly highlight the significant increase in canine C-reactive protein in dogs affected with canine monocytic ehrlichiosis. Although cytokines are considered as potent mediators of inflammatory reaction and their estimation has also been considered as indication about severity of inflammation associated with various infectious and non-infectious diseases, some extracytokine inflammatory mediators are also be synthesized in body by various tissue or organs during inflammation. Canine $\mathrm{C}$ reactive protein is one of these extra-cytokines inflammatory mediators which has been evaluated in ehrlichiosis affected dogs and compared with healthy one. From current study we can recommend the use of canine C-reactive protein estimation for assessing the severity of inflammation associated with canine monocytic ehrlichiosis.

\section{ACKNOWLEDGEMENTS}

The authors are thankful to Dean and Vice Chancellor DUVASU, for providing necessary facilities required for conducting present study.

\section{ETHICAL APPROVAL}

Approval was obtained from the Institutional Animal Ethics Committee (IAEC) of U.P. Pandit Deen Dayal Upadhyaya Pashu Chikitsa Vigyan Vishwavidyalaya Evam Go Anusandhan Sansthan (DUVASU) Mathura, India (approval no IAEC/18/8).

\section{REFERENCES}

Abiramalatha, T., Santhanam, S., Mammen, J.J., Rebekah, G., Shabeer, M.P., Choudhury, J. and Nair, S.C. 2016. Utility of neutrophil volume conductivity scatter (VCS) parameter changes as sepsis screen in neonates. J. Perinatol., 36(9): 733-738.

Asawakarn, S. and Taweethavonsawat, P. 2021. Characterisation of serum protein electrophoresis patterns and C-reactive protein in canine. Ticks Tick Borne Dis, 2: 1-10.

Barman, D., Baishya, B.C., Sarma, D., Phukan, A. and Dutta, T.C. 2014. A case report of canine ehrlichia infection in a labrador dog and its therapeutic management. BJVM., 12(2): 237-239.

Capsi, D., Snel, F.W., Batt, R.M., Bennett, D., Rutteman, G.R., Hartman, E.G., Baltz, M.L., Gruys, E. and Pepys, M.B. 1987. C-reactive protein in dogs. Am. J. Vet. Res., 48(6): 919-921.

Ceron, J.J., Eckersal, P.D. and Martinez-Subiela, S. 2005. Acute phase proteins in dogs and cats: Current knowledge and future perspectives. Vet. Clin. Pathol., 34: 85-99.

Cervoni, J.P., Thevenot, T. and Weil, D. 2012. C-reactive protein predicts short-term mortality in patients with cirrhosis. $J$. Hepatol., 6:1299-1304.

Eckersall, P.D. 2000. Recent advances and future prospects for the use of acute phase proteins as markers of disease in animals. Rev. Med. Vet., 151: 577- 584.

Harrus, S., Waner, T., Eldor, A., Zwang, E. and Bark, H. 1996. Platelet dysfunction associated with experimental acute canine ehrlichiosis. Vet. Rec., 139(12): 290-293.

Hayashi, S., Jinbo, T., Iguchi, K., Shimizu, M., Shimada, T., Nomura, M., Ishida, Y. and Yamamoto, S. 2001. A comparison of the concentrations of C-reactive protein and alpha1-acid glycoprotein in the serum of young and adult dogs with acute inflammation. Vet. Res. Comm., 25: 117-126.

Harrus, S. and Waner, T. 2011. Diagnosis of canine monocytotropic ehrlichiosis (Ehrlichia-canis): An overview. Vet. J., 187:292-296.

Higgins, M.A., Berridge, B.R., Mills, B.J., Schultze, A.E., Gao, H., Searfoss, G.H., Baker, T.K. and Ryan, T.P. 2003. Gene expression analysis of the acute phase response using a canine microarray. Toxicol. Sci., 74: 470-484. 
Karnezi, D., Ceron, J.J., Theodorou, K., Leontides, L., Siarkou, V.I., Martinez, S., Tvarijonaviciute, A., Harrus, S., Koutinas, C.K., Pardali, D. and Mylonakis, M.E. 2016. Acute phase protein and antioxidant responses in dogs with experimental acute monocytic ehrlichiosis treated with rifampicin. Vet. Microbiol., 184:59-63.

Kishimoto, T. 1989. The biology of interleukin-6. Blood, 74: $1-10$.

Kjelgaard-Hansen, M., Jensen, A.L., Houser, G.A., Jessen, L.R. and Kristensen, A.T. 2006. Use of serum C-reactive protein as an early marker of inflammatory activity in canine type II immune-mediated polyarthritis: case report. Acta. Vet. Scand., 48: 9 .

Kushner, I., Broder, M.L. and Karp, D. 1978. Control of the acute phase response. Serum C reactive protein kinetics after acute myocardial infarction. J. Clin. Investig., 161: 235-42.

Otabe,K., Ito, T., Sugimoto, T. and Yamamoto, S. 2000. C-reactive protein (CRP) measurement in canine serum following experimentally induced acute gastric mucosal injury. Lab. Anim., 34: 4

Pepys, M.B. and Baltz, M.L.1983. Acute phase proteins with special reference to C-reactive protein and related proteins (pentaxins) and serum amyloid A protein. Adv. Immunol., 34: 141-212.

Petersen, H.H., Nielsen, J.P. and Heegaard, P.M. 2004. Application of acute phase protein measurements in veterinary clinical chemistry. Vet. Res., 35: 163- 187.

Reardon, M.J. and Pierce, K.R. 1981. Acute experimental canine ehrlichiosis. II. Sequential reaction of the hemic and lymphoreticular systems of selectively immunosuppressed dogs. Vet. Pathol., 18: 384-395.
Rikihisa, Y., Yamamoto, S., Kwak, I., Iqbal, Z., Kociba G., Mott J. and Chichanasiriwithaya. 1994. C-Reactive Protein and a1-Acid Glycoprotein Levels in Dog Infected with Ehrlichia canis. J. Clin. Microbiol., 32(4): 912-917.

Riley, R.F and Coleman, M.K. 1970. Isolation of C-reactive proteins of man monkey, rabbit and $\operatorname{dog}$ by affinity chromatography on phosphorylated cellulose. Clin. Chim. Acta., 30: 483-96.

Sainz, A., Roura, X., Miro, G., Estrada-Pena, A., Kohn, B., Harrus, S. and Solano-Gallego, L. 2015. Guideline for veterinary practitioners on canineehrlichiosis and anaplasmosis in Europe. Parasites Vectors, 8: 75.

Shimada, T., Ishida, Y., Shimizu, M., Nomura, M., Kawato, K., Iguchi, K. and Jinbo, T. 2002. Monitoring C-reactive protein in beagle dogs experimentally inoculated with Ehrlichia canis. Vet. Res. Commun., 26: 171-177.

Yamamoto, S., Tagata, K., Nagahata, H., Ishikawa, Y., Morimatsu, M. and Naiki, M. 1992. Isolation of canine $\mathrm{C}$-reactive protein and characterization of its properties. Vet. Immunol. Immunopathol., 30: 329-339.

Yamasaki, K., Taga, T., Hirata, Y., Yawata, H., Kawanishi, Y., Seed, B., Taniguchi, T., Hirano, T. and Kishimoto, T. 1988. Cloning and expression of the human interleukin-6 (BSF-2) IFN- $\beta 2$ ) receptor. Science, 241: 825-828. 